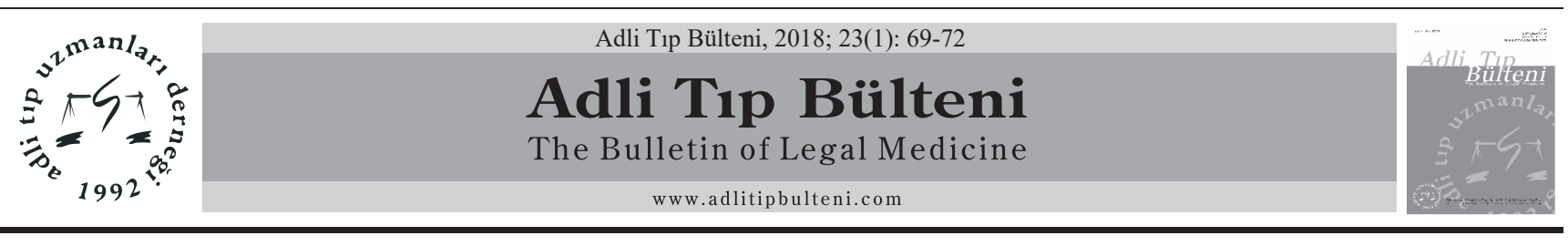

\title{
Klinik Bulgu Vermeyen Kafa İçi Travmalarının Yaşamsal Tehlike Kriterleri Açısından Yeniden Değerlendirilmesi: Olgu Sunumu
}

\author{
The Reevaluation of Intracranial Traumas Which Don't Have Clinical Findings in \\ Terms of Life-Threatening Criteria: Case Report
}

\author{
Yusuf Atan ${ }^{1}$, Murat Akbabal ${ }^{1}$, M. Kenan Asıldağ ${ }^{2}$, Zekeriya Tataroğlu ${ }^{1}$, Veysal Daş ${ }^{1}$ \\ ${ }^{1}$ Gaziantep Üniversitesi Tıp Fakültesi Adli Tıp Anabilim Dalı \\ ${ }^{2}$ Adli Tip Kurumu Gaziantep Adli Tip Şube Müdürlüğ̈̈
}

\section{Özet}

Kafa bölgesine yönelik ateşli silah yaralanmaları sonucunda genellikle kafatası kemiklerinde kırık, beyin kanaması ve beyin doku hasarı meydana gelmektedir. Türk Ceza Kanunu'na (TCK) göre her biri tek başına yaşamsal tehlikeye neden olan bu üç yaralanma genelde birlikte bulunur.

Bilindiği üzere orbitada kraniumla iştirakli; süperior ve inferior orbital fissür ve de optik sinirin geçtiği optik kanal olmak üzere 3 esas foramen vardır.

$\mathrm{Bu}$ çalışmada, ateşli silah çeşitlerinden biri olan pompalı tüfekle yüz bölgesinden yaralanan ve bir adet saçma tanesinin orbita çukurunu kemik kırı̆̆ı olmaksızın geçerek herhangi bir nörolojik semptom oluşturmaksızın beyin dokusunda kalan 39 yaşında bir kadın olgu sunulmuştur.

Olgu, saçma tanesinin orbita çukurundan kemik kırığına neden olmadan ilerleyerek beyin dokusuna isabet etmesine rağmen nörolojik bir semptom oluşturmaması fakat yaralanmanın vasıf olarak yaşamsal tehlikeye neden olan kriterler arasında olması açısından ilginç bulunmuş ve tehlike kriterinin belirlenmesinde; travmanın sadece lokasyonuna göre mi yoksa oluşturduğu hasara göre mi karar verilmesi gerektiği konusunu tartışmaya açmak amacı ile sunulmuştur.

Anahtar Kelimeler: İntrakranial Yabancı Cisim; Ateşli Silah Yaralanması; Yaşamsal Tehlike; Adli Tıp.

\begin{abstract}
Gunshot wounds, towards to the head frequently ends with the fractures of the skull, brain hemorrhage and brain tissue damage. Each of these three injury types cause life-threatening due to the Turkish Penal Code, and they are usually seen together.

As known, there are three basic foramens associated with cranium; superior and inferior orbital fissure and the optic channel which the optic nerve passes through.

In presented case, a 39 years old female patient who was shot with a pump rifle (a kind of gunshot type) from her face and one pellet which does not produce any bone fracture or neurological symptom while passing the orbital pit, is presented.

This case was found interesting because; even though these kinds of wounds are inside the criteria of life-threatening, in our case, the pellet which passes through the orbital pit did not produce any bone fracture, neurological symptom or brain tissue damage. In this study, it is aimed to discuss that should the life-threatening decision must be given just only according to the location of wound or should it be given according to the magnitude of damage?
\end{abstract}

Keywords: Intracranial Foreign Body; Gunshot Wounds; Life Threatening; Forensic Medicine.

\section{Giriş}

Ateşli silah yaralanmaları genel olarak; saldırı, intihar amaçlı ya da kaza sonucu meydana gelebilmektedir. Ateşli silah yaralanmaları dışında da penetran beyin yaralanmaları çok nadir rastlanabilen durumlardır (1). İntrakranial yabancı cisimler çoğunlukla göz, kulak ya da kafa kemiklerinin penetran yaralanmas1 neticesinde girerler $(2,3)$.

Tıbben "yaşamını tehlikeye sokan yaralanma" kavramı; bir yaralanma sonrası kişinin yaşamının mutlak su-

Sorumlu Yazar: Uzm. Dr. Yusuf Atan

Adli Tip Kurumu, Çankırı Adli Tıp Şube Müdürlüğ̈̈, Çankırı

E-mail: r.yusufatan@gmail.com

Geliş: 03.08.2016 Düzeltme: 19.06.2017 Kabul: 21.06.2017 retle tehlike altına girmesi neticesinde gerek kendi vücut direnci gerekse de tıbbi yardımla kurtulması durumunda kullanılır yani olay sırasında yaşamsal tehlikenin meydana gelmiş olması önemlidir. Kişinin sonradan komplikasyonsuz iyileşmesi veya herhangi bir belirti göstermeksizin genel durumunun düzelmesi "yaşamını tehlikeye sokan yaralanma" vasfinı değiştirmez $(4,5)$.

Genel olarak yaşamsal tehlikeye neden olan kafataS1 yaralanmaları değerlendirildiğinde; Kafatası kırıkları (Le Fort 3 ve orbita tavan kırı̆̆g gibi kafatasını oluşturan kemikleri de içerir), kafa içi kanama, kontüzyon, laserasyon, klinik olarak bulgu veren beyin ödemi ve başlangıç Glasgow Koma Skorunun 8 ve altında olduğu bilinç kapalılığı olarak sıralanmıştır $(4,5)$. 
5237 sayılı Türk Ceza Kanunu'nun 87/1. maddesinde ise "Kasten yaralama fiili, mağdurun; duyularından veya organlarından birinin işlevinin sürekli zayıflamasına, konuşmasında sürekli zorluğa, yüzünde sabit ize, yaşamını tehlikeye sokan bir duruma, gebe bir kadına karşı işlenip de çocuğunun vaktinden önce doğmasına neden olmuşsa, yukarıdaki maddeye göre belirlenen ceza, bir kat artırılır ancak verilecek ceza, birinci fikraya giren hallerde üç y1ldan, üçüncü fikraya giren hallerde beş yıldan az olamaz" şeklinde ifade edilmiştir.

Sunulan olguda herhangi bir klinik semptom olmasa (görme kaybı haricinde) dahi kafa içi travmatik değişimlerin hayati tehlikeye neden olacağ lanmalarında orbitada kemik kırığı olmaksızın geçişin olabileceği vurgulanmıştır.

\section{Olgu}

39 yaşında kadın hasta, aile içi anlaşmazlık neticesinde çıkan tartışmada pompalı tüfekle sağ gözünden yaralanmış, götürüldüğü sağlık kuruluşunda bilinç açık, genel durumu orta olarak değerlendirilmiş, sağ gözde yaralanmaya dair bulgular ve sol çenede 3 adet saçma tanesi yaralanması tespit edilmiştir.

Beyin tomografisi Radyoloji Anabilim Dalınca; (Beyin BT) intrakraniyal ve sağ orbital kavitede metalik dansite gösteren bir adet yabancı cisim, sağ bulbus okulide intraoküler kanama, retroorbital yağlı doku artışı ve hava kabarcıkları, sağ periorbital yumuşak dokuda travmaya bağl1 yumuşak doku şişliği, sağ bulbus okulide hipotoni olduğu şeklinde yorumlanmış ve beyin içinde herhangi bir travmatik değişimden bahsedilmemiştir. Kişi, kontrol amaçlı dört gün yoğun bakım ünitesinde yatırılarak takip ve tedavi edilmiştir. Hasta, gözündeki yaralanma nedeniyle Gaziantep Üniversitesi Şahinbey Araştırma ve Uygulama Hastanesi'ne başvurmuş, sağ gözde oluşan skleral perforasyon ve göz kapağı kesilerinin tedavisi için opere edilmiş, ameliyat sonrası sağ gözde görmenin olmadığ $1(\mathrm{P}-)$ tespit edilmiştir.

Operasyon sonrasında olgu, adli birimlerce mevcut yaralanmasına dair adli raporunun düzenlenmesi için Anabilim Dalımıza gönderilmiştir. Rutin adli tıp uygulamalarında kullanılan kılavuz incelendiğinde; kafa içi kanama, laserasyon ve kontüzyonun yaşamsal tehlike oluşturduğu belirtilmekle beraber asemptomatik kafa içi yaralanma ile ilgili bir bilgi verilmediğ görülmüştür (5).

Meydana gelen yaralanmanın asemptomatik olmas1na rağmen hayati önemi haiz bir organı ilgilendirmesi ve intrakranial bölgede metalik imaj veren yabancı cisim varlığı (Resim 1, 2, 3) gerekçeleri ile düzenlenen adli

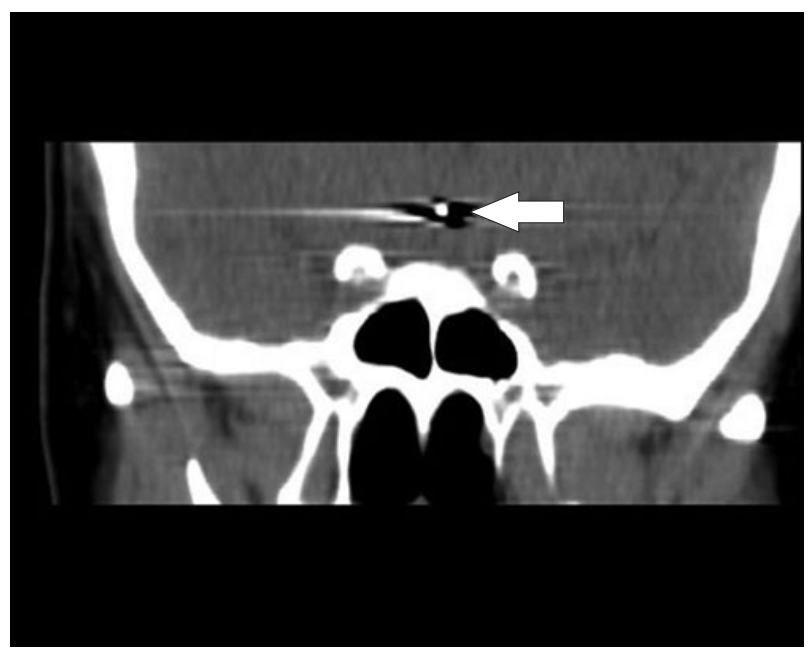

Resim 1. Beyin BT'de sagital düzlemde yabancı cisim görüntüsü.

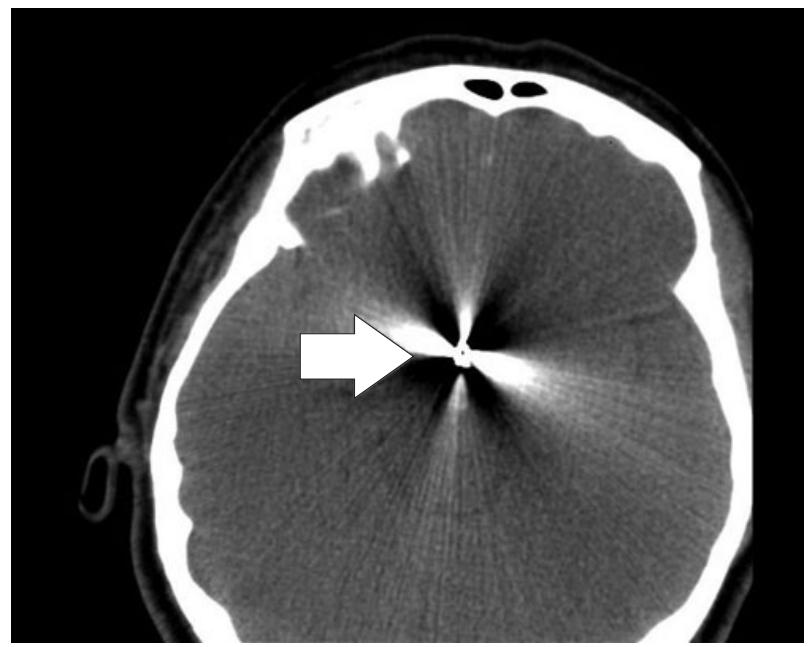

Resim 2. Beyin BT'de horizontal düzlemde yabanc1 cisim görüntüsü.

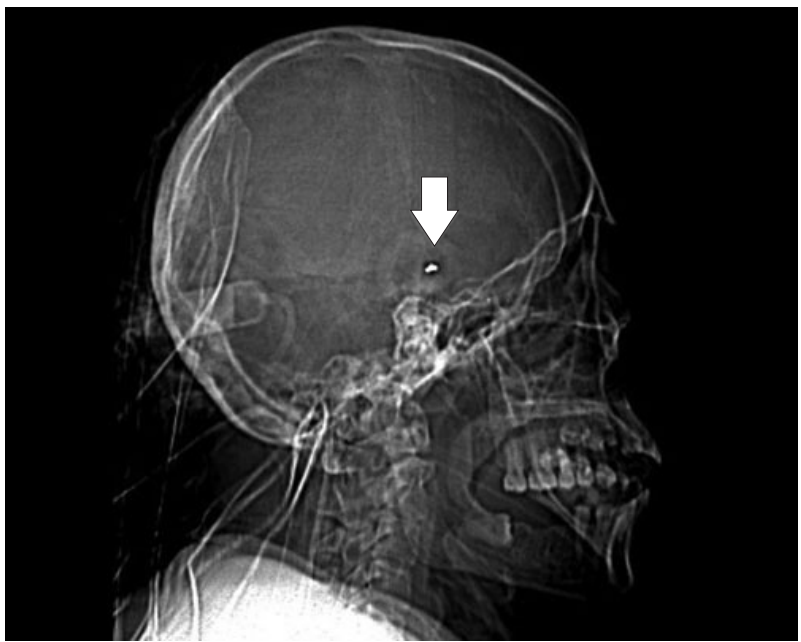

Resim 3. Lateral direkt kafa grafisinde yabancı cisim görüntüsü. 
raporda "yaşamsal tehlikeye neden olduğu" yönünde kanaat belirtilmiştir.

\section{Tartışma}

Olgu, aile içi tartışma sırasında pompalı tüfekle yaralanmış, sağ gözüne isabet eden iki adet saçma tanesinin sağ optik sinir bütünlüğünü bozmak suretiyle sağ gözde total görme kaybına neden olmuş ve sağ orbitadan kemik yapılarda fraktür meydana getirmeksizin intrakranial bölgeye geçmiştir. Ancak yukarıda da belirtildiği üzere olguda sağ gözde görme kaybı dışında herhangi bir nörolojik ve/veya serebral defisite neden olmamıştır.

Penetran kafa yaralanmaları neticesinde intrakraniyal yerleşim gösteren cisimlerin çıkarılması birtakım komplikasyonlara (beyin içi kanama, nöbet, enfeksiyon vb.) neden olma riski taşıdıklarından bu hastalarda cerrahi tedavi kararı önem taşımaktadır. Ayrıca bu tür olguların tedavisinde (özellikle derin yerleşimli veya ventriküllerde bulunan) fikir birliği de yoktur (6).

Transorbital intrakranial penetrasyon gösteren yaralanmalar genellikle yabancı cisimlerin orbital roof veya süperior orbital fissürden geçmesi sonucu oluşmaktadır $(7,8)$. Sunulan olguda kranium kemiklerinin bütünlüğünün bozulmadığının saptanması ve sadece optik sinirin hasar görmesi nedeniyle saçma tanesinin optik kanaldan geçerek kafa içine ulaştı̆̆ 1 düşünülmüştür. Ateşli silahla yaralanma sonucu oluşan kafatası travmalarında ölüm oranı oldukça yüksektir $(9,10,11) .319$ vaka üzerinden yapılan bir çalışmada ateşli silah ile yaralanma sonucu oluşan kafa travmaları Glasgow Koma Skalasına (GKS) göre sinıflandırıldığında GKS: 13-15 olan vakalarda ölüm oranı \%10.7, GKS: 9-12 olan vakalarda ölüm oran1 $\% 25$, GKS: $6-8$ olan vakalarda ölüm oranı $\% 71.5$, GKS 3-5 olan vakalarda ölüm oran1 \%98.5 olarak bulunmuştur (10). Sunulan olguda götürüldüğü ilk sağlık kuruluşunda yapılan muayenesi sonucunda GKS:13-15 olarak değerlendirilmiş ve sonrasında herhangi bir nörolojik defisit de meydana gelmemiştir.

Vücut içerisinde kalmış bir mermi çekirdeğinin zamanla ne şekilde bir değişim arz ettiği hususunda literatürde yeterli bilgi bulunmamaktadır (12). Fakat beyin omurilik sıvısında kalan mermi çekirdeğinin sistematik kurşun zehirlenmesine yol açtığ bildirilmiştir $(13,14)$. Ayrıca kurşun artropatisi ve psödokist gibi durumlara da yol açabilmektedir (12).

Türk Ceza Kanunu'na göre "yaşamsal tehlike" kavramı madde 87/1〉de tanımlanmıştır (4). Adli Tıp açısından yaralanmaların değerlendirilmesinde, tüm kafa içi travmatik değişimlerin yaşamsal tehlike oluşturduğu, kafa içi değişimlerin eşlik etmediği kraniyal sinir yaralanmaları- nın ise hayati tehlike oluşturmadığı kabul edilmektedir (5). Bu olguda ise radyolojik ve klinik olarak kafa içi değişim (kontüzyon, kanama, laserasyon vb.) saptanmamış olsa dahi yaralanmanın hayati bir organ olan beyni ilgilendirmesi ve bu tür vakalarda ölüm oranlarının yüksek olması nedeniyle yaşamını tehlikeye sokan bir duruma neden olduğu yönünde kanaat belirtilmiştir. Bu tür olgularda TCK 86-87. maddelere göre adli rapor tanziminde kullanılan kılavuzda yukarıda söz edilen konunun yeterince aydınlatılmamış olması nedeniyle "kafa içindeki asemptomatik yabancı cisimler" için "yaşamsal tehlikeye neden olduğu" şeklinde geliştirilebilecek bir yaklaşımın ne denli isabetli olacağının tartışılması gerektiği kanaatindeyiz. Ayrıca bu ve benzeri belirtilmemiş hususların aydınlatılmış olduğu yeni bir kılavuza ihtiyaç duyulduğunun altını çizmek istiyoruz.

\section{Kaynaklar}

1. Donnarumma P, Tarantino R, Gennaro P, Mitro V, Valentini V, Magliulo G et al.: Penetrating gunshot wound to the head: transotic approach to remove the bullet and masseteric-facial nerve anastomosis for early facial reanimation. Turkish Neurosurgery 24:415-8, 2014.

2. Callahan AB, Yoon MK: Intraorbital foreing bodies: retrospective chart review and review of literature. Int Ophthalmol Clin 53:157-65, 2013.

3. Chan SK, Pang KY, Wong CK: Transnasal penetrating intracranial injury with a chopstick. Hong Kong Med J 20:679, 2014.

4. Adli Tıp Ders Kitabı, İstanbul: Cerrahpaşa Tıp Fakültesi Vakfi Yayınları, 2011; 635-6.

5. Güzel S, Balcı Y, Çetin G. Adli Tıp Kurumu Başkanlığı Adli Tıp Uzmanları Derneği Adli Tıp Derneği, Türk Ceza Kanun'unda tanımlanan yaralanma suçlarının adli tip açısından değerlendirilmesi, 2005(Güncelleme Editörleri; Gündoğmuş ÜN, Balcı Y, Akın M. 2013);1-2.

6. Ozdol C, Ozdol N.C, Celikmez R.C, Turk C.C, Dogan O, Kara N.N; Incidentally detected intracranial multiple metallic foreign bodies. Türk Norosirurji Dergisi Cilt 25, Say1 1, Sayfa 55-7, 2015.

7. Miller CF, Brodkey JS, Colombi BJ. The danger of intracranial wood. Surg Neurol 1977;7:95-103.

8. Wesley RE, Anderson SR, Weiss MR, Smith HP. Management of orbital-cranial trauma. Adv Ophtal Plast Reconstruct Surg 1988;7:3-26.

9. Martins RS, Siqueira MG, Santos MT, Zanon-Collange N, Moraes OJ. Prognostic factors and treatment of penetrating gunshot wounds to the head. Surg Neurol 2003;60:98-104.

10. Miller JD, Butterworth JF, Gudeman SK, Faulkner JE, Choi $\mathrm{SC}$ et al.; Further experience in the management of severe head injury. J Neurosurg 1981;54:289-99. 
11. Cinar K, Secer M, Alagoz F, Ulutas M, Uckun OM ve ark.; Outcomes and demostration of cranial firearm injuries: a multicenter retrospective study. Ulus Travma Acil Cerrahi Dergisi, July 2015, Vol. 21, No. 4;291-6.

12. Oyar O, Yavuz MS, Koroglu M. A bullet that remained and deformed in the body. The Turkish Journal of Forensic Sciences, 2004;3(1):41-5.
13. Cavalieri-Costa R, Stape CA, Suzuki I, Targa WH, Bat1sta MA et al.; Lead poisoning caused by a bullet in the hip.report of 2 cases. Rev Hosp Clin Fac Med Sao Paulo, 1994;49:124-7.

14. Jansen DL, Tirman PFJ, Rabassa AE, Kumar S. Lead "bursogram" and focal synovitis secondary to a retained intraarticuler bullet fragment. Skeletal Radiology, 1995;24(2):142-4. 